\title{
Hydrogen peroxide photometric analysis of titanium in vanadium alloy
}

\author{
Qiang Yang ${ }^{\mathrm{a}}$, Guangping Tang ${ }^{\mathrm{b}}$, Qilong Wei ${ }^{\mathrm{c}}$, Lunfu Tian ${ }^{\mathrm{d}}$ \\ Institute of Machinery Manufacturing Technology, China Academy of Engineering Physics, \\ Mianyang, Sichuan, 621900, PRC \\ ayangqiang817@hotmail.com, 'Banquer@163.com, 'weiqilong2004@126.com, \\ dscopiontian@126.com
}

Keywords: Hydrogen peroxide photometric method, Titanium, Vanadium alloy

Abstract: The hydrogen peroxide photometric method for analyzing main constituent titanium in vanadium alloy were investigated in the paper, including the sample digestion method, chromogenic conditions, Lambert-Beer's law range, matrix interferences, method precision, recovery of standard addition, sample analysis and comparison analysis. The method precision in RSD\% was $2.6 \%$, the recoveries of standard addition were from $98.7 \%-99.4 \%$. The experimental results indicated that the proposed method for determination of titanium in vanadium alloy was simple, fast, accurate, and easy to operate, which was suitable for quality control of vanadium alloy.

\section{Introduction}

Vanadium alloy is a kind of important material with important application, its quality must be ensured, in which its chemical constituents and mechanical properties are important parameters which must be controlled, in which titanium is one of the main constituents which must be controlled and determined [1].

The determination method of titanium includes FAAS method [2], GFAAS method [3], ICP-AES method [4], indirect AAS method [5], derivative spectrophotometry [6], hydrogen peroxide-photometric method [7], alternating current voltammetry method [8], gravimetric method [9], titration method [10] and etc.. In the above methods, the hydrogen peroxide photometric method was widely used in determination of titanium in various metal or alloy materials, which had advantages of being fast, accurate, cheap and easy to operate. But in analysis of vanadium alloy, matrix vanadium seriously interfered with the signal of titanium in the hydrogen peroxide photometric method. The later method could not be directly used in determination of titanium in vanadium alloy. Therefore it was needed to study how to remove the interference from vanadium during the determination of titanium in vanadium alloy.

In the present study, titanium in vanadium alloy was determined by $\mathrm{H}_{2} \mathrm{O}_{2}$ spectrophotometric method with subtraction of matrix signal, and the results indicated that the proposed method was simple, accurate, and easy to operate, which was suitable for quality control of vanadium alloy.

\section{Experimental}

\section{Instrumentation}

A model 721 Spectrophotometer (Shanghai No.3 analytical instruments factory, China) was employed in determination experiments.

\section{Reagents}

$\mathrm{HCl}(1+1), \mathrm{H}_{2} \mathrm{O}_{2}, \mathrm{HNO}_{3}(1+1), \mathrm{H}_{2} \mathrm{SO}_{4}(1+1)$, sulfuric and phosphorus acids mixture (SP hybrid 
acids) used in the experiments were all analytical reagents grade and purchased from market.

Titanium standard solution $\left(1000 \mathrm{mg} \cdot \mathrm{L}^{-1}\right)$, Chromium standard solution $\left(1000 \mathrm{mg} \cdot \mathrm{L}^{-1}\right)$ was prepared by high purity metal. Vanadium standard solution $\left(1000 \mathrm{mg} \cdot \mathrm{L}^{-1}\right)$ was prepared by dissolving $\mathrm{NH}_{4} \mathrm{VO}_{3}(\mathrm{AR}, 99.0 \%)$ in pure water.

\section{Analytical procedure}

$0.1000 \mathrm{~g}$ of vanadium alloy sample was digested in $10 \mathrm{ml} 1+1 \mathrm{H}_{2} \mathrm{SO}_{4}$ under slightly heating, and $1+1 \mathrm{HNO}_{3}$ was added dropwise into the solution to remove purple color, and boiling was used to drive off $\mathrm{NO}_{\mathrm{x}}$. After cooling, the solution was transferred into a $100 \mathrm{ml}$ volumetric flask, and adjusted to the mark. $5 \mathrm{ml}$ of sample solution was pipetted to make chromogenic solution, and then the solution's absorption was determined at a wavelength of $410 \mathrm{~nm}$ by a spectrophotometer. Absorption of titanium was equal to that of sample chromogenic solution minus that of matrix calibration solution. The content of titanium was then calculated by calibration curve.

Matrix calibration solution: pipetting $4.5 \mathrm{ml}$ of $1000 \mathrm{mg} / \mathrm{L} \mathrm{V}$ solution $+2.5 \mathrm{ml}$ of $100 \mathrm{mg} / \mathrm{L} \mathrm{Cr}$ solution, adding $5 \mathrm{ml} 1+1 \mathrm{H}_{2} \mathrm{SO}_{4}$, shaking it, and then adding $2 \mathrm{ml} \mathrm{H}_{2} \mathrm{O}_{2}$, adjusting to $50 \mathrm{ml}$.

Sample chromogenic solution: pipetting $5 \mathrm{ml}$ of sample solution, adding $5 \mathrm{ml} 1+1 \mathrm{H}_{2} \mathrm{SO}_{4}$, shaking it, and then adding $2 \mathrm{ml} \mathrm{H}_{2} \mathrm{O}_{2}$, adjusting to $50 \mathrm{ml}$.

\section{Calibration curve}

A three points calibration curve of titanium was plotted according to the determination results from a series of titanium standard calibration solutions, including $0,10.00,20.00 \mathrm{mg} \cdot \mathrm{L}^{-1}$ three

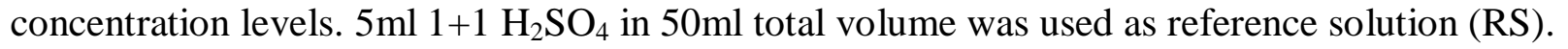

\section{Results and discussion}

\section{Selection of digestion method}

The solubility of vanadium alloy in different acids was still not completely known, therefore we carried out digestion method experiments, and selected suitable acid according to experimental results. The result of the digestion method experiments was given in table 1 .

Table 1 Effect of digestion method on determination results

\begin{tabular}{ccccc}
\hline Digesting acid & $1+1 \mathrm{HCl}+\mathrm{H}_{2} \mathrm{O}_{2}$ & $1+1 \mathrm{HNO}_{3}$ & $1+1 \mathrm{H}_{2} \mathrm{SO}_{4}$ & SP hybrid acids \\
\hline Sample weight $(\mathrm{g})$ & 0.1000 & 0.1000 & 0.1000 & 0.1000 \\
\hline Acid Volume $(\mathrm{ml})$ & $10+12.5$ & $10+10$ & 10 & 10 \\
\hline Digestion time $(\mathrm{min})$ & 30 & 10 & 10 & 15 \\
\hline Digestion effect & $\begin{array}{c}\text { partially } \\
\text { dissolved }\end{array}$ & $\begin{array}{c}\text { Completely } \\
\text { dissolved }\end{array}$ & $\begin{array}{c}\text { Completely } \\
\text { dissolved }\end{array}$ & $\begin{array}{c}\text { Completely } \\
\text { dissolved }\end{array}$ \\
\hline Solution color & Light green & Light green & Deep blue & Deep green \\
\hline Remark & Not good & Good & Good & Good \\
\hline
\end{tabular}

According to table $1,10 \mathrm{ml} 1+1 \mathrm{H}_{2} \mathrm{SO}_{4}$ was selected for further experiments. 


\section{Selection and optimization of determination conditions}

\section{Absorption Spectrum}

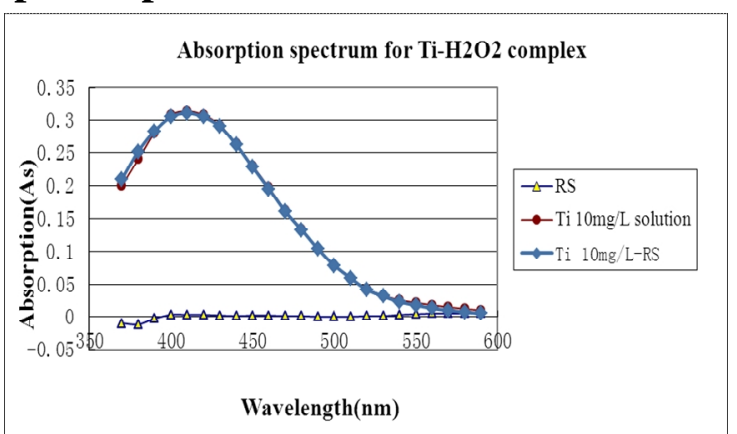

(a)

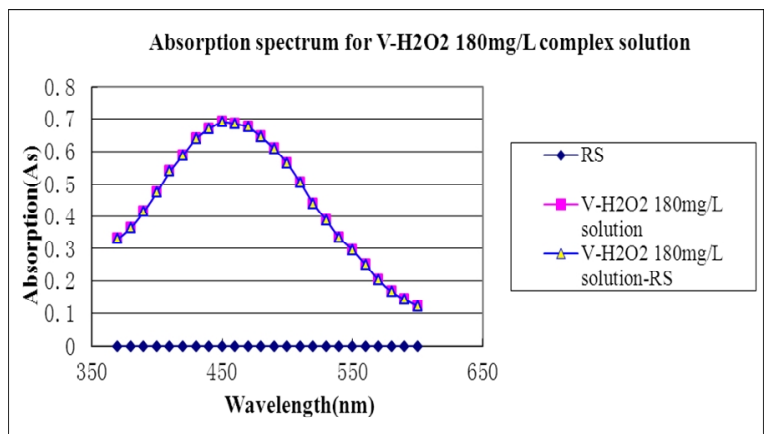

(b)

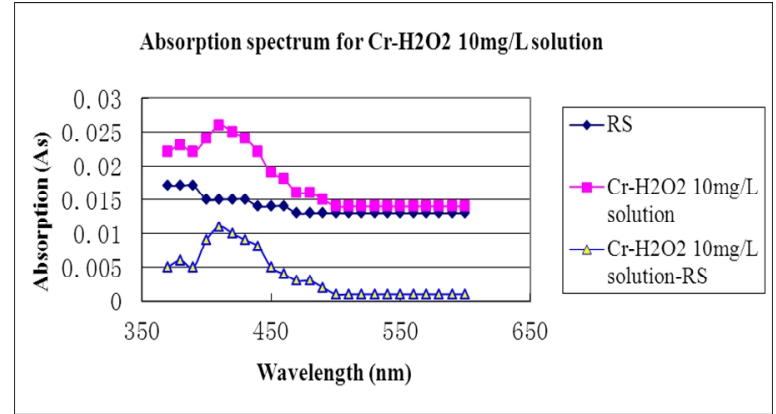

(c)

Figure 1 Absorption spectrum for $\mathrm{Ti}-\mathrm{H}_{2} \mathrm{O}_{2}$ complex solution (a) and $\mathrm{V}-\mathrm{H}_{2} \mathrm{O}_{2}$ complex solution (b) and $\mathrm{Cr}-\mathrm{H}_{2} \mathrm{O}_{2}$ complex solution (c)

From figure 1, we knew that the absorption maximum for $\mathrm{Ti}-\mathrm{H}_{2} \mathrm{O}_{2}$ complex solution appeared at a wavelength of $410 \mathrm{~nm}$, therefore we chose $410 \mathrm{~nm}$ as determination wavelength for further experiments. Vanadium- $\mathrm{H}_{2} \mathrm{O}_{2}$ complex had strong interference on absorption on $\mathrm{Ti}-\mathrm{H}_{2} \mathrm{O}_{2}$ complex at 410nm, and $\mathrm{Cr}-\mathrm{H}_{2} \mathrm{O}_{2}$ complex also had slight interference on Ti- $\mathrm{H}_{2} \mathrm{O}_{2}$ complex at 410nm, which should be subtracted as background from total absorption.

\section{Selection of volume of Chromogenic reagent}

Experimental conditions were as following : [Ti] $=10 \mathrm{mg} / \mathrm{L}$, volume of $1+1 \mathrm{H}_{2} \mathrm{SO}_{4}=10 \mathrm{ml}$,

volume of chromogenic reagent $\mathrm{H}_{2} \mathrm{O}_{2}: 1.0,2.0,3.0,4.0,5.0 \mathrm{ml}$.
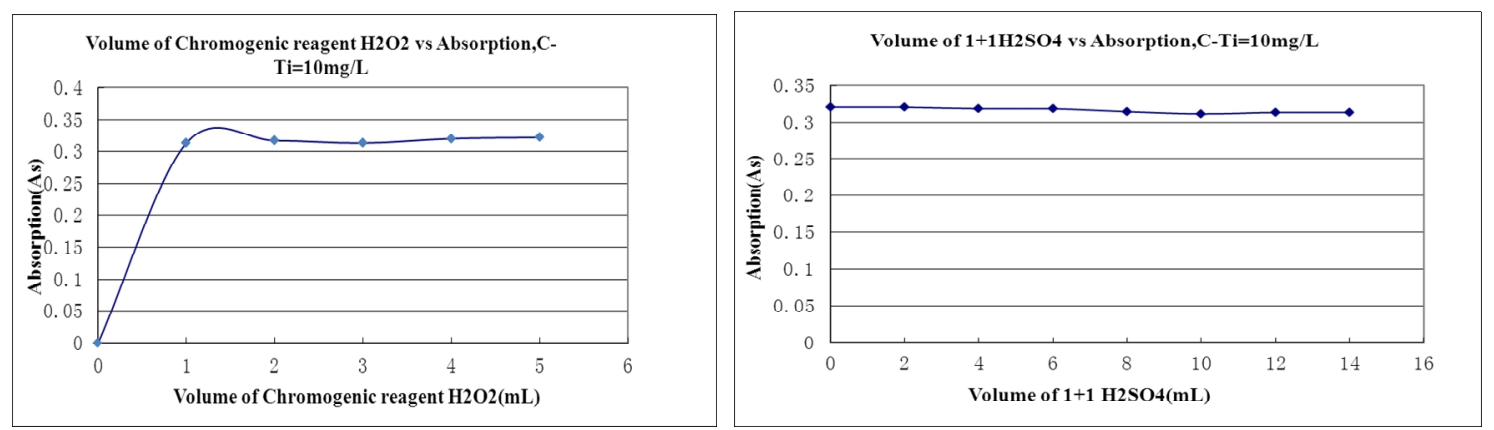

Figure 2 Effect of volume of chromogenic reagent $\mathrm{H}_{2} \mathrm{O}_{2}$ (left) and chromogenic acid $1+1 \mathrm{H}_{2} \mathrm{SO}_{4}$ (right) on absorption of titanium- $\mathrm{H}_{2} \mathrm{O}_{2}$

From figure 2(left), we known that the absorption basically kept unchanged when the volume 
of chromogenic reagent $\mathrm{H}_{2} \mathrm{O}_{2}$ was between 1.00 to $5.00 \mathrm{ml}$, to save chromogenic reagent, we chose $2 \mathrm{ml}$ as the volume of chromogenic reagent $\mathrm{H}_{2} \mathrm{O}_{2}$ for further experiments.

\section{Selection of chromogenic acidity (volume of $1+1 \mathrm{H}_{2} \mathrm{SO}_{4}$ )}

From figure 2(right), we known that the absorption of titanium basically kept unchanged when the volume of chromogenic acid $1+1 \mathrm{H}_{2} \mathrm{SO}_{4}$ was between $2 \mathrm{ml}$ to $14 \mathrm{ml}$, to make analysis easy and to prevent $\mathrm{Ti}$ ion from hydrolysis, we chose $5 \mathrm{ml}$ as the volume of chromogenic acid $1+1 \mathrm{H}_{2} \mathrm{SO}_{4}$ for further experiments.

\section{Selection of chromogenic time}

We carried out stability (chromogenic time) experiments, the concentration of Ti solution was $10 \mathrm{mg} / \mathrm{L}$, and the main result within $1 \mathrm{~h}$ was given in figure 3 . The absorption of the same chromogenic solution after $17 \mathrm{~h}$ was 0.316 As, slightly decreased compared to that within $1 \mathrm{~h}$.

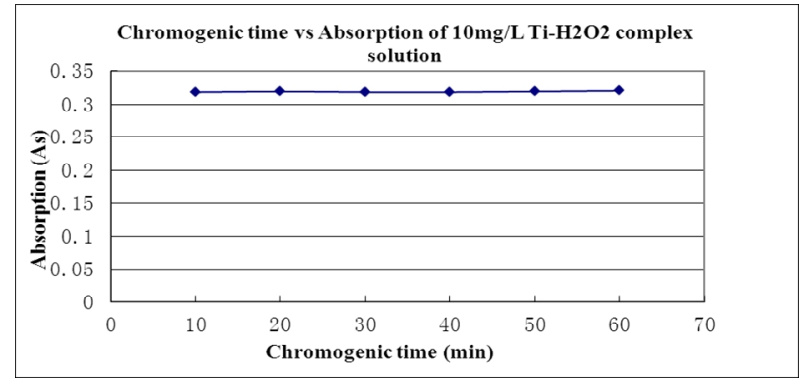

Figure 3 Selection of chromogenic time

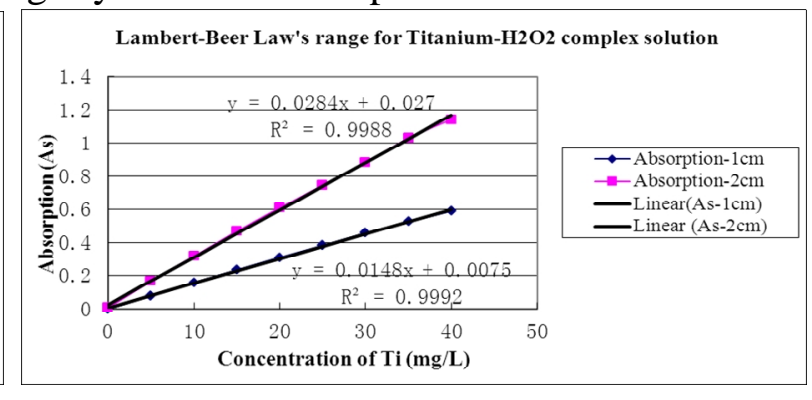

Figure 4 Lambert-Beer's law range at 410nm

From figure 3, we saw that the absorption almost kept unchanged within 60 min, to make the absorption stable enough, we chose 20-30min as the chromogenic time for further experiments.

\section{Lambert-Beer's law range}

From figure 4, we knew that lambert-beer's law was best obeyed from 0 to $40 \mathrm{mg} / \mathrm{L}$ for $1 \mathrm{~cm}$ cell, and from 0 to $35 \mathrm{mg} / \mathrm{L}$ for $2 \mathrm{~cm}$ cell. For vanadium alloy, the calibration graph practically used for $1 \mathrm{~cm}$ cell was in concentration range from 0 to $20 \mathrm{mg} / \mathrm{L}$.

\section{Matrix interference experiments}

The main constituents of vanadium alloy are vanadium, chromium and titanium. After 0.1000 gram sample was digested and adjusted to $50 \mathrm{ml}$ and had a dilution of 10 , the concentration of vanadium, chromium and titanium in test solution were ca. $180 \mathrm{mg} \cdot \mathrm{L}^{-1}, 10 \mathrm{mg} \cdot \mathrm{L}^{-1}, 10 \mathrm{mg} \cdot \mathrm{L}^{-1}$, respectively. After matrix interference experiments, we found that the vanadium had serious interference on the absorption of $\mathrm{Ti}-\mathrm{H}_{2} \mathrm{O}_{2}$ solution, and chromium also had slight interference on the absorption of Ti- $\mathrm{H}_{2} \mathrm{O}_{2}$ solution.
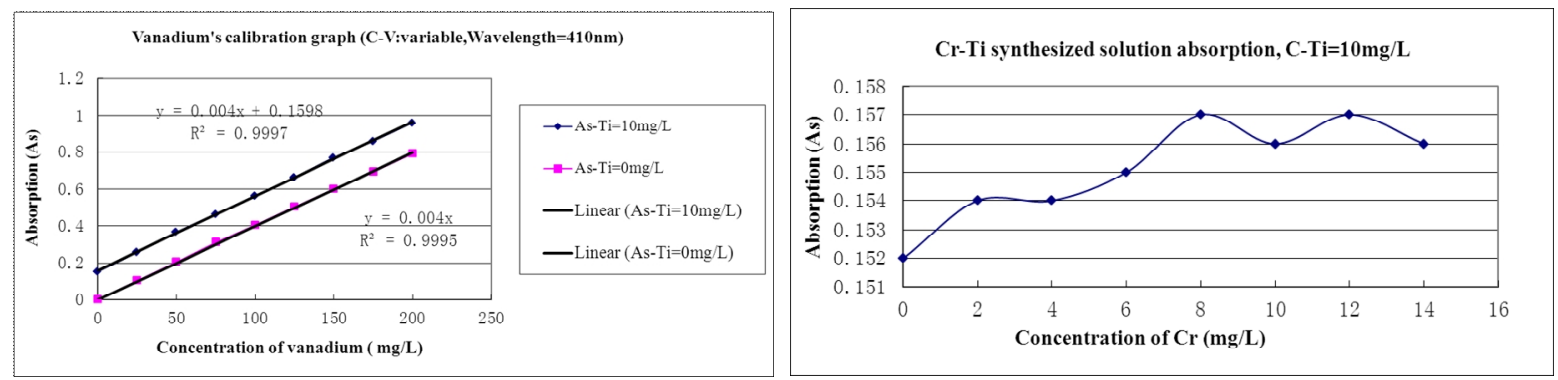

Figure 5 Effect of the $\mathrm{V}$ (left) and $\mathrm{Cr}$ (right) concentration on absorption of Ti- $\mathrm{H}_{2} \mathrm{O}_{2}$ complex

$$
\text { ( C-Ti=10mg/L ) }
$$

From figure 5(left) we saw that the two vanadium calibration graphs with titanium and without titanium were parallel to each other, indicating that the absorption of vanadium $-\mathrm{H}_{2} \mathrm{O}_{2}$ complex and titanium- $\mathrm{H}_{2} \mathrm{O}_{2}$ complex had good additivity, and the total absorption of sample solution is the sum of that of vanadium and that of titanium. The concentration of vanadium in test solution was about 
$180 \mathrm{mg} / \mathrm{L}$, its absorption should be subtracted from the total absorption when calculating the content of titanium. From figure 5(right) we saw, when Cr's concentration was in range of 8-12mg/L, the delta absorption of Cr-Ti solution was only 0.004-0.005 As. The concentration of $\mathrm{Cr}$ in the test solution was about $10 \mathrm{mg} / \mathrm{L}$, and its absorption should be subtracted as background from the total absorption when calculating the content of Ti.

\section{Method Validation}

\section{Method precision}

6 runs of individual determinations (1 sample in each run) were carried out with newly prepared series calibration solutions in each run, and the results were given in table 2. From table 2 we found that the method precision in RSD\% was $2.6 \%$.

Table 2 Precision data $(\mathrm{n}=6)$

\begin{tabular}{cccc}
\hline Sample Number & $\begin{array}{c}\text { Averaged determination } \\
\text { content }(\overline{\mathrm{X}} / \mathrm{WT} \%)\end{array}$ & $\begin{array}{c}\text { Standard } \\
\text { derivation } \\
(\mathrm{SD} / \%)\end{array}$ & $\begin{array}{c}\text { Relative standard } \\
\text { derivation } \\
(\mathrm{RSD} / \%)\end{array}$ \\
\hline $1 \# \sim 6 \#$ & 5.45 & 0.14 & 2.6 \\
\hline
\end{tabular}

\section{Recoveries of standard addition}

The recovery experiments of standard addition included two groups, group A was carried out with addition of titanium standard solution before sample digestion, and group B was carried out with addition of titanium standard solution after sample digestion, 1 samples was used in each experiment, and the results were given in table 3. From table 3 we knew that the recoveries of standard addition were between $98.7 \%-99.4 \%$, which could meet the requirement of determination.

Table 3 Analytical results and recoveries

\begin{tabular}{ccccc}
\hline Sample No. & $\begin{array}{c}\text { Average content } \\
\left(\mu \mathrm{g} \cdot \mathrm{ml}^{-1}\right)\end{array}$ & $\begin{array}{c}\text { Added } \\
\left(\mu \mathrm{g} \cdot \mathrm{ml}^{-1}\right)\end{array}$ & $\begin{array}{c}\text { Found } \\
\left(\mu \mathrm{g} \cdot \mathrm{ml}^{-1}\right)\end{array}$ & Recovery (\%) \\
\hline Group A & 5.22 & 5.00 & 10.19 & $99.4 \%$ \\
\hline Group B & 5.51 & 10.00 & 15.38 & $98.7 \%$ \\
\hline
\end{tabular}

Sample analysis and comparison experiments

6 samples were analyzed by the proposed method, and determination results were listed in table 4. From table 4, we saw that the results determined by the proposed method were in good agreement with the comparison data by ICP-AES method. It indicated that the proposed method has good accuracy enough to satisfying the requirements of determination.

Table 4 sample analysis and comparison experiments

\begin{tabular}{ccc}
\hline Sample No. & Found by the method (Wt\%) & Found by ICP-AES * $(\mathrm{Wt} \%)$ \\
\hline 1\#-6\# & $5.51,5.53,5.64,5.41,5.41,5.22$ & $5.55,5.44,5.60,5.46$
\end{tabular}

Note*: The content data for comparison by ICP-AES method was provided by National Center of Analysis and Testing for Non-ferrous Metals \& Electronic Materials (No.2 Xinjiekouwai Street, Beijing, 100088, China) for the same batch of samples.

\section{Conclusion}

The proposed method for analysis of titanium in vanadium alloy was simple, fast, precise and 
easy to operate, which could practically meet the requirement of quality control of vanadium alloy.

\section{Acknowledgements}

The authors would like to gratefully acknowledge the Institute of Machinery Manufacturing Technology, China Academy of Engineering Physics (CAEP) for financial support.

\section{References}

[1] S. Huang, Chinese forum on nuclear technology and its application, subsection by CAEP youth scientific association, 2009, 261-264.

[2] C.S. Saba, K.J. Eisentraut, Anal. Chem., 1977, 49(3), 454-457.

[3] A. Asfaw, G. Webitoe, Anal. Bioanal. Chem., 2004, 379, 526-531.

[4] Y.K. Agrawal, S. Sudhakar, Talanta, 2002, 57, 97-104.

[5] C.L. Chakrabarti, M. Katyal, Anal. Chem., 1971, 43(10), 1302-1303.

[6] A. Varghese, A.M.A. Khadar, B. Kalluraya, Spectrochimica Acta Part A, 2006, 64, 383-390.

[7] C. S. Bergstresser, Anal. Chem., 1957, 29(4), 532-534.

[8] C. Locatelli, F. Fagioli, T. Garai, C. Bighi, Anal. Chem., 1988, 60(21), 2402-2408.

[9] H. T. Beans, D.R. Mossman, Anal. Chem., 1932, 54(5), 1905-1911.

[10] G. E. F. Lundell, H.B. Knowles, Anal. Chem., 1923, 45(11), 2620-2623. 